\title{
The Giving Legal Aid For The Poor On A Criminal Case
}

\author{
Ramdhan Kasim \\ Faculty of Law, Universitas Gorontalo
}

\begin{abstract}
The purpose of this study is to know and examine and analyze the nature of the provision of legal aid for the poor in criminal cases and to know and review and analyze the role of Legal Aid Organizations in Providing Legal Aid for the Poor in criminal cases. as well as to know and examine and analyze what factors influence the implementation of legal aid of the Poor in criminal cases.
\end{abstract}

Keywords : legal aid, criminal case

\section{INTRODUCTION}

Increasingly active legal involvement into issues of social change raises issues that lead to the conscious and active use of the law as a means to contribute to the new order of life. This is seen in terms of regulation by law, both in terms of legitimacy and aspects of the effectiveness of its application. The emerging problems are thus shifted from how to regulate in accordance with the legal procedure, to how the arrangement is so that in society there will be effects which are indeed desired by law. One of the efforts to achieve justice or equality in law is by legal aid for every citizen involved in legal cases, but in reality legal aid can only be felt by people who can afford only.

Indonesia as a law country has given its recognition, guarantee, and protection to Human Rights containing equality in the political, legal, social, economic, and cultural fields as stated in the Constitution and various Laws and Regulations as legal products of the Indonesian nation. One of them is stated in Indonesia, Law No. 8 year 1981 on the Law of Criminal Procedure. ${ }^{1}$

Upon the entry into force of the Criminal Procedure Code, the system / pattern of examination changes into the accusatoir system. System / pattern of examination with the principle of akusatur. placing the suspect as the subject of the examination. M. Yahya Harahap points out that, "Suspects must be placed in human positions with dignity and dignity. He should be judged as a subject, not as an object ". Recognition of the suspect is no longer the most important thing, in addition to the recognition of the suspect is also still needed other evidence. Another issue of concern is regarding the provision of legal

\footnotetext{
${ }^{1}$ La Ode Husen, et all, Community policing is a study in south Sulawesi, Imperial Journal of Interdisipnary Research, 2017, Vol.3 Issue, 5, p. 1026-1030.
} 
assistance during the HIR and after the enactment of the Criminal Procedure Code. ${ }^{2}$ Enactment of Criminal Procedure Code, there are restrictions on the provision of legal aid during the HIR, so as not to fulfill the sense of justice and to fulfill the rights of suspects and defendants. M. Yahya Harahap states that: However HIR only permits legal assistance to the defendant in the face of court hearings. As for the suspects in the investigation level investigation process, HIR has not granted the right to legal assistance. Accordingly, HIR has not granted the right to obtain and relate to a legal advisor at all levels of examination. Only limited after entering the examination stage in court. Likewise, the "duty" for judicial officials to appoint legal counsel is limited to criminal offenses punishable by death. Outside of the offenses that are threatened with the death penalty, there is no obligation for the court to appoint legal counsel to provide legal assistance to the defendant. ${ }^{3}$

After the entry into force of the Criminal Procedure Code, these restrictions are no longer valid. Article 54 of the Criminal Procedure Code states that, "In the interest of defense, a suspect or defendant is entitled to legal assistance from one or more legal counsels during and at each examination level". Legal assistance is a very important right held by suspects and defendants for the sake of their defense, and as guardians of the rights of suspects and defendants in criminal justice. Through the provision of legal assistance, it is desirable to achieve a criminal court that reflects a fair and impartial judiciary.

\section{ANALYSIS AND DISCUSSION}

\section{Providing Legal Aid to the Poor in Criminal Cases}

Legal aid is essentially a program that is not only a cultural act, but also a structural action aimed at the change of the unjust social order to a society that is better able to provide a comfortable breath for the majority. Therefore, legal aid is not a simple matter. It is an act of liberation from the shackles of the political and economic structures laden with oppression.

The conceptualization of legal aid is not to avoid the goal of restructuring people from sharp structural aggression by creating power centers and at the same time redistributing powers to exercise participation from below. The Constitution guarantees the right of every citizen of hell to be treated equally before the law, including the right to access justice through the provision of legal assistance. ${ }^{4}$ The rich and powerful, easily

\footnotetext{
${ }^{2}$ M. Yahya Harahap, 2007, Pembahasan Permasalahan Dan Penerapan KUHAP; Penyidikan dan Penuntutan; Edisi ke dua, Sinar Grafika, Jakarta, h. 134.

${ }^{3} \mathrm{lbid}$

${ }^{4}$ Rosenfeld, Michel, the Rule of Law and the Legitimacy of Constitutional Democracy, Southern California Law Review, 1992, Vol. 35, Issue,1995, p. 7-8, to the rule of law is a necessary condition to the realization
} 
accessing and obtaining "justice", through the hands of the lawyers he hired. Unlike the poor, they lack the ability to understand the law and are unable to pay for advocates, thus leaving no equal treatment before the law to access justice. The basic problem that arises is the lack of equal access for every citizen to get equal treatment before the law, although his doctrine of justice must be accessible to all citizens without exception. ${ }^{5}$ Indonesia is a developing country, so challenges are found in this country. One of them is the increasing number of poor people in Indonesian villages. Approximately approximately 13 million households live as farm laborers and legal services in Indonesia are still urban, and have not even touched on the root of the problems facing many urban poor.

As stated, poverty has complex dimensions and characteristics that tend to vary in each region (local-specific). Therefore, poverty should be described in such a way that policy interventions through poverty alleviation programs can be done more realistically by determining the most appropriate indicator of poverty conditions and possible to be handled.

As one form of local policy, the provision of legal assistance for the poor must take into account the real condition of the people of Gorontalo Province. The regulatory outreach on the provision of legal assistance to the poor is the fulfillment of equal status in the law, which among other things is marked by the creation of a situation in which the right of everyone to obtain equal treatment before the law and guarantee to every person who has the right to access justice all). This objective is important because the state is always faced with the fact that a group of poor or disadvantaged communities often can not realize their right to obtain justice (which should be implemented in relation to the concept of the rule of law).

Legal aid as an implementation of the equality before the law principle that is Human Rights, makes it a universal right that has been recognized, guaranteed, and given by other countries in the world. This right has also been regulated in a variety of international instruments that also serve as guidelines in the provision and implementation of Legal Aid in Indonesia. The arrangement of legal aid at the international level comprising of various international instruments, including arrangements on legal aid and also covering the principle of equality before the law include, Article 5, 6 ,

of a legitimate constitutional democracy in a pluralist polity. The concept of "the rule of law" is, like other key concepts such as "liberty" or "equality," much praised, but its meaning is much contested. Starting from the premise that legitimacy in the context of pluralism requires some form of consensus or its functional equivalent, this article examines the possible role of the rule of law, by analyzing the latter in terms of its evolution in three different traditions, namely that of the German "Rechtsstaat", the French "Etat de droit" and the Anglo-American "rule of law". Drawing on legal/constitutional jurisprudence, legal and political philosophy, and the place of judicial

${ }_{5}$ Pujiono, Bantuan Hukum dalam Perspektif Tanggungjawab Negara, Makalah disampaikan dalam Kegiatan Seminar "Bantuan Hukum dan Akses terhadap Keadilan Bagi Masyarakat Marginal", Semarang , 09 Pebruari 2010 
7, and 10 The Universal Declaration of Human Rights and Article 14 sub 3d, 16, and 26 International Covenant on Civil and Political Rights. 'The provision of legal aid on the basis of equality before the law may also be found in various Congresses and International Conventions, as international instruments, namely: World Conference on the Independence of Justice c.q. Universal Declaration on the Independence of Justice. Eight United Nations Congress on The Prevention of Crime and The Treatment of Offenders. Other instrumens adopted by the congress tepatnya pada bagian Basic Principles on The Role of Lawyers tentang Access to Lawyers and Legal Service. Convention Against Torture and Other Cruel, Inhuman or Degrading Treatment of Punishment.

Since the Republic of Indonesia became independent until now, normative legal aid arrangements do show good progress, when compared to previous times. The regulation of legal aid in its development now guarantees and protects the rights of persons or groups of poor people entitled to legal aid. The regulation of legal assistance has substantially improved towards more responsive and comprehensive laws, but, nevertheless, the legal instruments governing legal aid are of course still lacking or weaknesses that need to be assessed and addressed towards improvement for more legal reform Well again.

The Criminal Procedure Code has regulated the provision of legal aid as a suspect's and defendant's rights, but there are still shortcomings or weaknesses in the substance, namely in terms of restrictions on the recipients of legal aid. As set forth in the Criminal Procedure Code, legal assistance shall be granted to a suspect or defendant suspected or charged with a criminal offense punishable by capital punishment or criminal threat of fifteen years or more or for those unable to be threatened with a crime of five years or more Which does not have its own legal counsel so that suspects or defendants who are unable to face criminal charges under five years are not eligible for legal assistance or in this case the official concerned shall not be required to appoint legal counsel to this class or group.

Prior to the coming into effect of Law no. 16 of 2011 on Legal Assistance, the provision of legal aid is regulated in Government Regulation no. 83 of 2008 on Requirements and Procedures for Provision of Legal Assistance free of charge, if compared, there are similarities and differences in the arrangement. The difference is the difference in the use of the term. Government Regulation no. 83 of 2008 on the Requirements and Procedures for Providing Legal Assistance for Free use the term "Free Legal Assistance", while Law no. 16 Year 2011 About Legal Aid uses the term "Legal Aid" which means the same with free legal aid. Government Regulation no. 83 of 2008 concerning Requirements and Procedures for Provision of Legal Assistance free of charge which determines that the legal aid providers are advocates and Legal Aid / 
Advocate Organizations, and Law no. 16 Year 2011 About Legal Assistance determining legal aid providers is Legal Aid and Community Organizations. The setting of sanctions in both regulations is also different.

Regulatory differences between Law no. 16 Year 2011 on Legal Assistance with Government Regulation No. 83 Year 2008 on Requirements and Procedures for Provision of Legal Assistance is a change as an improvement effort, with the establishment of more comprehensive and effective legislation. The existence of different provisions in these two rules is certainly a weakness that can lead to legal uncertainty and influence in the implementation of providing legal assistance for persons or groups of the poor in criminal cases. Not only are the differences in the use of the term, if there is also a blurring of norms that can lead to multiple interpretations of the size of "people or groups of the poor" as recipients of legal aid, it will also have an impact on the implementation.

With the enactment of RI Government Regulation no. 42 Year 2013 on Terms and Procedures for Providing Legal Aid and Distribution of Legal Aid Funds as the implementer of Law No. 16 of 2011 on Legal Assistance, making the existence of three legal bases in the provision of legal aid in Indonesia. As the implementing regulation of the Law of the Republic of Indonesia Number 16 Year 2011 on Legal Assistance, the Government Regulation No. RI. 42 Year 2013 on Terms and Procedures for Legal Assistance and Distribution of Legal Aid Funds in line with the principles contained in Law of the Republic of Indonesia No. 16 of 2011 on Legal Assistance. Closing provisions Article 42 of RI Government Regulation no. 42 Year 2013 on the Terms and Procedures for Providing Legal Aid and Distribution of Legal Aid Funds states that, "When this Government Regulation comes into force, all implementing regulations governing Legal Aid shall remain valid as long as they do not conflict with the provisions of this Government Regulation".

\section{Relations of legal aid organizations and Advocates as legal aid providers in Law Enforcement.}

Implementation of law in society is very dependent on the legal consciousness of a society because it becomes the subject of law. But in addition to depending on the legal awareness of the community is also dependent and is largely determined by the implementation of law enforcement by law enforcement officers. Therefore many laws that can not be done well because law enforcers lack of understanding in carrying out their duties and responsibilities.

Basically, law enforcement can be done well if the elements of society and law enforcement elements are mutually sustainable in upholding the principle, the purpose of 
law and the provision of legal aid. The provision of legal assistance may be provided by an advocate or legal aid organization or Legal Aid Institute to a justice seeker or society.

Legal aid organizations or legal aid organizations are born because of a goal in helping people who are not able both economically and socially. It is also motivated by the desire to uphold justice and the same position before the law. If we see that in many instances the law is often blunt and upward but very sharply downward, this is where the advocates are needed to help lower middle-class people in legal processions. The advocate profession / legal adviser is a noble and honorable profession, performs the job of enforcing the law in court with the prosecutor and the judge (official's of the court) in whose job duties are under the protection of law and law which in this case is the Law No. 18 of 2003 on Advocates. The function of an advocate if we look at what has been regulated by law in court is to observe the performance of other legal practitioners.

For every problem an advocate is required to have a courage in seeking justice by putting aside any fear to anyone. The most important thing is the function of an advocate is to provide legal assistance to anyone to get justice. That is why an advocate should provide free legal assistance to any underprivileged and under-covered society who is blind to the law, whether involving criminal or civil matters.

Soerjono Soekanto, stated that the advocacy process at least provides legal assistance includes the following possibilities:

1. Giving legal information, for example, notifying a civil servant of his rights and obligations as a civil servant.

2. Providing legal advice, for example, explains what a person should do to buy a house or land.

3. Granting of Legal Services, for example, helps a person to compile a lawsuit.

4. Legal Guidance, ie continuous service delivery.

5. Providing intermediary services, for example, connecting citizens with certain instasi relating to the legal issues it faces.

6. Being a power of citizens within or outside the court. ${ }^{6}$

In the present time the widespread legal aid is also the awareness of various advocates in the field of legal aid. The establishment of legal aid institutions not only stands among practitioners is also widespread among academics especially legal aid that is assumed by law faculty in various universities both public and private in Indonesia. It aims in addition to providing assistance in seeking justice to the community as well as a place for students to practice their knowledge, also a place that can show that the theory

${ }^{6}$ Prodjohamidjojo, Martiman (1982) Seri Pemerataan Keadilan 5; Penasihat Dan Organisasi Bantuan Hukum. Jakarta: Ghalia Indonesia. 
sometimes does not match the reality on the ground. The community is getting easier to seek justice in aid and legal services because there are so many Legal Aid Institutions established in court offices or every post in the neighborhood. The goal is that any complaints and reports of the community can be directly accommodated and served.

From the above explanations it is clear that the Functions and Roles of legal aid agencies are as follows:

1. Public service. With regard to socio-economic conditions because most of our society is classified as incapable or less able to use and pay for advocate services, the Legal Aid Institution provides its services free of charge;

2. Social education. With regard to socio-cultural conditions, where institutions with a mature and systematic planning and practical work methods should provide illuminations and instructions to educate the public to be more aware of and understand their legal rights and obligations.;

3. Improved legal order. In relation to social politic conditions, where the role of the institution is not only limited to general judicial improvements to the defense profession in particular, it can also perform the work of the Ombudsman as the participation of the community in the form of control with its critics and suggestions for Improve the lameness / correction of actions of the authorities that harm society;

4. Law renewal. From practical experiences in performing its functions the institution finds many obsolete legal regulations that do not meet new needs, sometimes even contradicting or impeding the development of circumstances. Institutions may pioneer the proposed amendments to the law;

5. Job Opening (Labor Market). Given the fact that there is currently no unemployment of law graduates who are not or have not been used or deployed on jobs relevant to their fields in the framework of national development. The Legal Aid Institute if it can be established throughout Indonesia, for example, one Legal Aid office, in every district capital, many law graduates can be accommodated and utilized.

Practical training. The last function that is no less important and even needed by the institution in approaching itself and maintaining good relationship with science centers is the cooperation between institutions and local law faculties. This cooperation can provide benefits to both parties. For institutional law faculty can be a place of practice for law students in order to prepare themselves to become law graduates where students 
can test the theories learned with the realities and needs in practice and thus gain experience.

Providing legal assistance to persons or groups of the poor is an implementation effort of a legal state that recognizes, guarantees and protects human rights. Legal assistance is also provided as an effort to meet the needs of access to justice and equality before the law. In the implementation of legal aid, an advocate as a person providing legal assistance certainly has an enormous obligation and role in this regard. The legal subject of a criminal offense is entitled to legal assistance. In a person's criminal case, especially from the time when it is committed and / or detained the right to contact and seek the assistance of legal counsel in assisting in the settlement of cases by upholding Pancasila, law and justice. Guarantees of Indonesian citizens suspected of committing crimes entitled to legal aid in accordance with Article 54 of the Criminal Procedure Code states that, "In the interest of defense, the defendant or defendant is entitled to legal assistance from one or more legal counsels during and at each examination level". Legal assistance is a very important right held by suspects and defendants for the sake of their defense, and as a guardian for the rights of suspects and defendants in criminal justice. Through the provision of legal assistance, it is desirable to achieve a criminal justice that reflects a fair and impartial judicial process.

principle, each person can provide legal assistance if he has expertise in the field of law, but for the sake of orderly implementation of legal assistance given limitations and requirements in various regulations. The next issue is who should act to be the implementer of legal aid in our country today, given the large and diverse range of legal aid providers that can be classified as follows:

1. Advocate who is a member of an Advocate organization and also a member of the Legal Aid Institute.

2. Advocate who is a member of an Advocate organization and not a member of the Legal Aid Institute;

3. Advocate acting as Legal Counsel of a company;

4. Advocates who are not members of any association;

5. Lawyers Practice or Pokrol;

6. Law graduates working in law firms / government agencies;

7. Lecturers and Students of Faculty of Law;

8. Legal consultants.

The above-mentioned classifications can indeed act as legal aid providers in general, but are they also acting as legal aid providers to the poor (public defender) ?. In this case, the handling of legal aid to the poor should be done by professionals, those who are not only educated law graduates but who pursue the provision of legal aid as 
their basic daily work. This is ideally a legal aid program for the poor. But the reality we see shows the professionals described above are not numerous and the distribution is unevenly distributed from one place to another. Thus, those who should hold the main position in this relationship is the Advocates not only Advocates who are under the auspices of the Legal Aid Institute.

The form of legal aid referred to by the Advocate may be a legal service provided to any person in need, in terms of protection of the presumed lawsuit. This protection shall be granted because in addition to the provisions of the Act, a Suspect / Accused shall have rights guaranteed in the Constitution. Often poor people are treated unfairly and can not afford adequate access to legal counsel from Advocates (legal counsel). Fundamentally legal aid is the right of the pro poor can be obtained (pro bono publico) as a translation of equality before the law. In fact, in the use of advocate services would require the cost and how may the person who to meet the basic needs of his life alone can not afford, let alone pay the services of advocates, to overcome this problem, then provided legal assistance to the people or groups of the poor. According to Article 22 paragraph (1) of Law no. 18 of 2003 on Advocates states that, "Advocates shall provide free legal assistance to unfair justice seekers". Article 2 of Government Regulation no. 83 of 2008 on Requirements and Procedures for the Provision of Legal Aid for Free also states that, "Advocates are obligated to provide free legal assistance to seekers of justice". Article 12 paragraph (1) of Government Regulation No. 83 Year 2008 on Requirements and Procedures for Providing Legal Assistance free of charge further stipulates that "Advocates are prohibited from rejecting requests for Free Legal Aid". Based on the Indonesian Advocates Association Regulation No. 1 Year 2010 Concerning the Implementation Guidance of Free Legal Assistance applicable to advocate organizations states that, Advocates are encouraged to provide free legal assistance of 50 hours / year. These provisions have clearly indicated that lawyers are obliged to provide legal assistance to persons or groups of the poor.

Article 1 Sub-Article 1 of Law Number 16 Year 2011 on Legal Assistance states that, "Legal Assistance is a legal service provided by the Legal Aid for free to the Legal Aidee". Article 1 Sub-Article 1 of Government Regulation 42 Year 2013 Concerning Terms and Procedures for Providing Legal Aid and Fund Disbursements 6 Legal Assistance also provides the same definition of legal aid. Based on this it can be seen that, legal aid is a legal service provided free of charge. Law no. Law No. 16 Year 2011 on Legal Assistance also regulates the obligation of advocates in providing legal assistance to persons or groups of the poor, as provided for in article 10 letter e stating that the Legal Aid is obliged to: provide Legal Assistance to the Legal Aid based on the terms and ordinances which is prescribed in this Act until the case is completed, unless 
there is a valid legal reason. Legal aid is a right for the people or groups of the poor who have been regulated in various international and national instruments. As a universally recognized right which is the actualization of Human Rights and equality before the law then, the right to legal aid has been known and given for a long time. The definition of legal aid free of charge has also been expressly regulated in Article 1 number 3 PP. 83 of 2008 on the Requirements and Procedures for the Provision of Legal Assistance free of charge which states that, "Free legal aid is a legal service provided by an advocate without receiving payment of honorarium includes providing legal consultations, exercising power, representing, accompanying, defending, And take other legal actions for the benefit of justice seekers who can not afford ".

Not many know that legal aid is part of the Advocate profession. The obligation to defend the poor for the Advocate profession is inseparable from the principle of equality before the law and the right to be accompanied by Advocates who are human rights for all without exception, including the justice for all. However, it may not be all Advocates who will be engaged in this field, but only certain Advocates are specifically directed to address the issue of providing legal assistance to the poor. For this purpose, it is necessary to regenerate young militant Advocates who have been prepared from college.

\section{The Role of Legal Aid Organizations in the Provision of Legal Aid to the Poor to criminal cases}

Legal assistance is an important instrument in the Criminal Justice System because it is part of the protection of Human Rights for every individual, including the right to legal aid. The direction of legal development is increasingly emphasizing the importance of access to legal aid for the poor and marginalized groups of people. The poor face major obstacles not only in financial matters relating to the cost of the case, but also identical to the low level of education, which implies a lack of knowledge of the legal issues when it comes to bringing the case to the Court. The poor face major obstacles not only in financial matters relating to the cost of the case, but also identical to the low level of education, which implies a lack of knowledge of the legal issues when it comes to bringing the case to the Court. Before discussing the results of the analysis of the data collected at the research sites, will be explained in advance about the basic provision of legal assistance especially legal assistance in criminal cases conducted by the Legal Aid Organization.

Djoko Prakoso states that, the provision of legal assistance in the criminal process is a principle of a legal state which in the preliminary examination stage is manifested by determining that, for the purpose of preparing the defense, the suspect has the right to appoint, contact and seek the assistance of legal counsel. The suspect is 
entitled to legal aid at the time of preliminary investigation at the investigation level. ${ }^{7} \mathrm{M}$. Yahya Harahap states that, "What is meant by investigation examination is the investigation in front of investigator officials by presenting suspects, witnesses, or experts. Inspection means that the investigating officer is directly opposite the suspects, witnesses or experts. ${ }^{8}$

The investigation of the suspect at the investigation level is a series of suspect checks to be set forth in an Official Report. The Criminal Procedure Code has explicitly set out the procedures for the investigation of suspects. In relation to the provision of legal aid, as set out in the Criminal Procedure Code, it is known that, before the investigator conducts an investigation of a suspect, the investigator is obliged to notify him of his right to legal assistance or in the case shall be accompanied by a legal advisor, as provided for in Article 114 KUHAP. Article 56 of the Criminal Procedure Code specifies that, legal assistance is provided to a suspect or defendant with the following classifications or criteria:

1. Legal assistance shall be granted to a suspect or defendant suspected or charged with crime that is threatened with: Sentence of death or 15 years or more. For those who can not afford those who are threatened with a crime of five years or more who do not have their own legal counsel;

2. The officer concerned at all levels of examination in the judicial process shall appoint legal counsel to the suspect or defendant, if it meets the criteria or based on that classification.

3. In accordance with Article 56 of the Criminal Procedure Code, there is no obligation for the official concerned to appoint legal counsel for a suspect or defendant classified as a person or group of poor people entitled to legal assistance, if the suspect or defendant commits a crime punishable under 5

The provision of legal aid in criminal cases at the trial stage of the defendant in court, in addition to referring to the Criminal Procedure Code, has issued guidance for the courts in the implementation of legal assistance as set forth in Supreme Court Regulation Number 1 Year 2014. Supreme Court Regulation No. 1 Year 2014 issued on January 16, 2014 on Guidelines for the Provision of Legal Services for the poor in court. then there has been guidance on the implementation of legal assistance at the stage of examination of the defendant in the District Court session.

As set forth in the Supreme Court Regulation No. 1 of 2014 issued on 16 January 2014 on Guidelines for the Provision of Legal Services for the poor in Court. "The implementation and use of the legal aid budget within the General Courts is

${ }^{7}$ Djoko Prakoso dan I Ketut Murtika, 1987, Mengenal Lembaga Kejaksaan di Indonesia, Bina Aksara, Jakarta, h. 27.

${ }^{8}$ M. Yahya Harahap, op.cit, h. 129. 
covering 3 (three) scopes namely 1. Cash Cost Cutting Services, 2. Session of the court outside the building and 3. Pene $\neg$ dian Post Court legal aid. There are 4 types of legal assistance that can be provided in the provision of legal aid namely, Legal Aid Post, Advocate Assistance Services, Crime Agreement Exemption both Criminal and Civil, and Cost of Session at Zitting Plaats or outside court sessions. The existence of this Legal Aid Post, certainly shows the role of the State in providing facilities and facilities in the provision of legal aid in the District Court. Judges in the district courts in the implementation of legal aid also refer to Article 56 of the Criminal Procedure Code.

In the implementation still refers to the provisions of Article 56 of the Criminal Procedure Code which stipulates that the defendant charged with a criminal offense punishable by capital punishment or 5 (five) years or more shall be granted legal assistance. This provision imperatively must be satisfied, therefore, if the defendant is threatened with a crime of 5 (five) years or more, then the judge shall provide legal counsel, if this is not fulfilled by the judge, it shall be null and void so that the judiciary shall be repeated. The defendant charged with a criminal offense punishable by a criminal under 5 (five) years shall not be granted legal assistance ".

\section{CONCLUSION}

The nature of the provision of legal assistance to the poor in criminal cases is the fulfillment of the equality of the status of law, which among other things is marked by the creation of a situation in which the right of every person to obtain equal treatment before the law and guarantee to everyone who is entitled to access justice. The role of legal aid organizations in the implementation of providing legal assistance for the poor in criminal cases can not be implemented properly (not yet effective) because of deviations in practice. Factors affecting the implementation of legal assistance for persons or groups of the poor in criminal cases can be classified and differentiated, ie substance, legal structure, and legal culture.

\section{REFERENCE}

Ahmad, Kamri, and Hardianto Djanggih. "Batasan Penerapan Asas Persidangan Terbuka untuk Umum dalam Siaran Persidangan Pidana oleh Media." Jurnal Hukum lus Quia lustum, Volume. 24. Issue. 3. (Juli 2017).

Djoko Prakoso dan I Ketut Murtika, 1987, Mengenal Lembaga Kejaksaan di Indonesia, Bina Aksara, Jakarta. 
La Ode Husen, et all, Community Policing Is A Study In South Sulawesi, Imperial Journal of Interdisipnary Research, 2017, Vol.3 Issue, 5.

Rosenfeld, Michel, the Rule of Law and the Legitimacy of Constitutional Democracy, Southern California Law Review, 1992, Vol. 35, Issue,1995.

Pujiono, Bantuan Hukum dalam Perspektif Tanggungjawab Negara, Makalah disampaikan dalam Kegiatan Seminar "Bantuan Hukum dan Akses terhadap Keadilan Bagi Masyarakat Marginal”, Semarang , 09 Pebruari 2010.

Prodjohamidjojo, Martiman (1982) Seri Pemerataan Keadilan 5; Penasihat Dan Organisasi Bantuan Hukum. Jakarta: Ghalia Indonesia.

Yahya Harahap. M., 2007, Pembahasan Permasalahan Dan Penerapan KUHAP; Penyidikan dan Penuntutan; Edisi ke dua, Sinar Grafika, Jakarta 